\title{
Corrigendum: Generation of stem cell-derived $\beta$-cells from patients with type 1 diabetes
}

Jeffrey R. Millman, Chunhui Xie, Alana Van Dervort, Mads Gürtler, Felicia W. Pagliuca \& Douglas A. Melton

Nature Communications 7:11463 doi: 10.1038/ncomms11463 (2016); Published 10 May 2016; Updated 4 Aug 2016

The source of reagents for this Article was not fully acknowledged. The Acknowledgements should have included the following:

'We thank Professors Robin Goland and Dieter Egli (https://www.cellhub.org) for patient fibroblasts.'

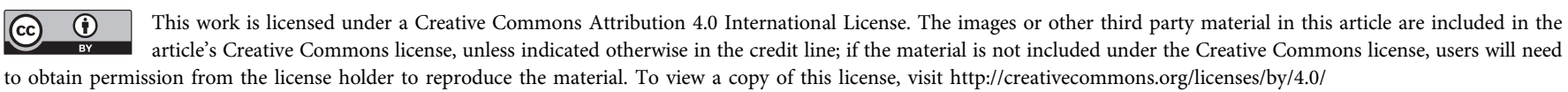

